Reproduced from Of Palm Wine, Women and War: The Mongolian Naval Expedition to Java in the 13th Century, by David Bade (Singapore: Institute of Southeast Asian Studies, 2013). This version was obtained electronically direct from the publisher on condition that copyright is not infringed. No part of this publication may be reproduced without the prior permission of the Institute of Southeast Asian Studies. Individual articles are available at <http://bookshop.iseas.edu.sg>

\title{
OF PALM WINE, WOMEN AND WAR
}


The Institute of Southeast Asian Studies (ISEAS) was established as an autonomous organization in 1968. It is a regional centre dedicated to the study of socio-political, security and economic trends and developments in Southeast Asia and its wider geostrategic and economic environment. The Institute's research programmes are the Regional Economic Studies (RES, including ASEAN and APEC), Regional Strategic and Political Studies (RSPS), and Regional Social and Cultural Studies (RSCS).

ISEAS Publishing, an established academic press, has issued more than 2,000 books and journals. It is the largest scholarly publisher of research about Southeast Asia from within the region. ISEAS Publishing works with many other academic and trade publishers and distributors to disseminate important research and analyses from and about Southeast Asia to the rest of the world. 


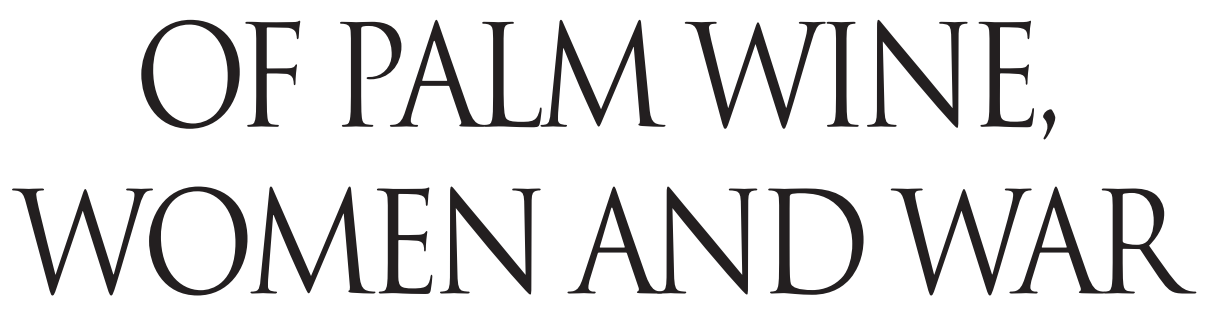

The Mongolian Naval Expedition to Java in the 13 th Century

DAVID BADE 
First published in Singapore in 2013 by

ISEAS Publishing

Institute of Southeast Asian Studies

30 Heng Mui Keng Terrace

Pasir Panjang

Singapore 119614

E-mail: publish@iseas.edu.sg

Website: http:/ /bookshop.iseas.edu.sg

All rights reserved. No part of this publication may be reproduced, stored in a retrieval system, or transmitted in any form or by any means, electronic, mechanical, photocopying, recording or otherwise, without the prior permission of the Institute of Southeast Asian Studies.

(C) 2002 David W. Bade

The responsibility for facts and opinions in this publication rests exclusively with the author and his interpretations do not necessarily reflect the views or the policy of the Institute or its supports.

\section{ISEAS Library Cataloguing-in-Publication Data}

Bade, David W.

Of palm wine, women and war : the Mongolian naval expedition to Java in the $13^{\text {th }}$ century.

Revised edition of the author's work entitled: Khubilai Khan and the beautiful Princess Tumapel : the Mongols between history and literature in Java. Ulaanbaatar: A. Chuluunbat, 2002.

1. Java (Indonesia)—History-Mongol Invasion, 1293.

2. Java (Indonesia) - History-Mongol invasion, 1293-Historiography.

3. Mongols-Indonesia-Java-Historiography.

4. Javanese literature-History and criticism.

5. Kublai Khan, 1216-1294-In literature.

I. Title: Khubilai Khan and the beautiful Princess Tumapel

DS646.27 B131 2013 2013

ISBN 978-981-4517-82-9 (soft cover)

ISBN 978-981-4517-83-6 (e-book, PDF)

Cover photo (top): Scenes Sanggramawijaya defeated Mongolia after defeating Jayakatwang forces in staging the colossal dance drama Throne Wilwatikta by STUPA community in Yogyakarta Cultural Park Auditorium, 5 December 2012. This dance drama tells the story of the establishment of the kingdom of Majapahit by Narrarya Sanggramawijaya helped Duke Wiraraja of Sumenep by defeating forces Jayakatwang and Mongolia.

Source: TEMPO/STR/Suryo Wibowo, Indonesia.

Cover photo (bottom): Relief from Candi Jago, constructed near Malang, east Java, in 1280 in memory of a deceased king, Wisnuwardhana, by his son Kertanagara. The temple bears reliefs from a Buddhist text, Kunjarakarna, in which the main deity is Vairocana. This relief may depict Vairocana and a female deity in a garden. Courtesy of Professor John N. Miksic

Typeset by Superskill Graphics Pte Ltd

Printed in Singapore by Oxford Graphic Printers Pte Ltd 
For my daughter Khulan

Охин Хуландаа зориулав 
